\title{
The Urgency of Hasan Hanafi's Hermeneutics in Understanding Religion at Globalization Era
}

\author{
Nurkhalis \\ Ph.D student at State Islamic University of North Sumatra (UINSU), Medan, Indonesia \\ Lecturer at State Islamic University of Ar-Raniry Aceh, Indonesia
}

\begin{abstract}
Agreement or diasagreement in devoting hermeneutics into the basic truth happens in interpreting Qur'āni. Hermeneutics don't want a discourse great ultimed truth but a consideration grounded. Religion is formed based on some characteristics of interpretation as ziyadahhermeneutics, it is an interpretation in text expansion, nuqșan hermeneutics(not perfect), less than a load of text. Whereas qillahhermeneutics (minus)is an interperetation to use a half or a quarter of the payload text. Hanafi categorized the charge hermeneutics with some forms of them; wașfi hermeneutics(natures/names), natural hermeneutics, madi hermeneutics (substance), shuri hermeneutics(figurative/orientation). Understanding religion appears dichotomic between adopt turāts Islam than Qur'āni or westernization. So the understanding of Islam eroded in interpretation humanistics, liberalistics, modernistics, feministics, pluralistics and anakronistics. Hanafì introduces a hermeneutical theory with the approach of istimbāt istiqra'i (exploration deductive). Istiqra' understood with istaqraitu be regarded with 'I've been testing hard' one theme from the text of The Scriptures. The movement of renewal of Islam in contemporary will transfer 'ishlah dīn (reform religion) to naḥdhah syāmilah' (resurrection performance) as a way of obtaining the medieval to suggest transformation or revolution of the social religious. The transition from 'nahdhah syāmilah' will give birth to the enlightenment sense through imaging inclusive in unify vision begins from the realization of Islam; it was from left to the Islamic right, or conversely assuming maslahah (welfare).
\end{abstract}

Keywords:- hermeneutics; Islam; globalization; religion

\section{INTRODUCTION}

The Islamic and modernization discourse has been increasingly opened by being characterized the more and more concept of Islam accumulated in renewal order. One of the very conspiratorial ideas today is about hermeneutic idea which becomes unfinished project that continues developing according to the intellectual message as new theory formulators in creating a new civilization in Islam. Some Islamic intellectuals equate Hermeneutic with tafsir (commentary), while the others state differently. During this time the use of interpretative term in Qur'an has a connotation with the use of tafsir interpretations method. Many tafsir rules follow the principle and strict pattern, while the pattern of hermeneutic interpretation follows the open pattern. Hermeneutic becomes the icon of the modernization of al-Quran values in which the examination interval ranged in transnational perspective which synonymous with the political interpretation based on the inspiration to try to advocate liberalism, modernism, humanism and feminism in the discourse of sanctity which has always focused on alienation. Meanwhile in the next limit the hermeneutic is pushed towards mono dimensional which accommodates political development in a pure religion culture which is decorated by a monolithic and normative reflection leads to generation cycle confrontation. ${ }^{1}$ Muslim society in globalization and modernization era are faced with the choice between exploring the values of al-Qur'an and hadith which are renewable or receiving the construction of mazhab view as products of history. In Islamic jurisprudence it has been determined the limit of Sahih (valid) as the truth accumulation of Permanent understanding the mazhab version, while khatha (wrong) is the deviation of sahih corridor and the views of dhal (misguided) that is an understanding which is far from the sahih corridor which tends to different from the should be action.

Finally in understanding of religion occurs class action between agreeing on closed ijtihad or inviting a call for open ijtihad. Actually, the existence of tafsir and hermeneutics gives a major contribution to the responsibility that religion is a guide to eliminate any doubt, conflict and oppression. The Islamic intellectuals put hermeneutic to dissect back Islam in the frame of modernization and local wisdom until it is initiated in the

\footnotetext{
${ }^{1}$ Meena Sharify-Funk, Encountering the Transnational: Women, Isläm and the Politics of Interpretation, (England: Ashgate Publishing Company, 2008), p. 38 and 32 
level of ideas reconstruction, rethinking and deconstruction. This effort was done to arouse the Muslims to give a thinking view like juridical review towards the old thoughts which are tested again in the form of modern Islamic paradigm. There are some classical Islam scholars who consider Islam has a single truth. While the paradigm modern of thought considers the Islamic concept should not be single but many united varieties only in the rule of Islam. The ultimate goal of the Sacred Text is to provide moral and ethical guidance. But morality does not end with the Qur'an it is only a basic assumption. In essence the spirit of Islam is declared that the moral should start from al- Qur'an. ${ }^{2}$

The application of Islamic hermeneutics is not distinguished by Muslin scholars with hermeneutics philosophy. Either Islamic hermeneutics or hermeneutic philosophy, it has thinking corridor towards a more rational way by considering other aspects to strengthen the understanding of the Qur'anic interpretation. Hermeneutic does not want a soar discourse, while the hermeneutic philosophy in its existence is always concerned with utopist rational truth. The existence of revelation opens the horizons more elegant to several living choices between positive and negative offerings, good-bad, or measurable or not measurable.

Understanding the truth of Muthlak Al-Qur'an is extremely limited. No one knows which one a single meaning is. Then the understanding of individualism on Al-Qur'an caused the emergence of pros and cons about the essence and the substance of Al-Qur'an values. There is a contradiction in society between echoing AlQur'an with a simple concept or with the soar concept. During this time many Muslims do not understand AlQur'an evenly, the result is a sharp deviation that leads to the conflicts like the weakening of Islamic faith, the differences and the rejection of Shari'ah (Islamic law) etc. The rejection is something that cannot be tolerated on the discourse of Al-Qur'an in order to echo Al-Qur'an on earth. In fact there is violence in the name of religion that is understood by a group of people as the validity who legalizes any violence to defend the faith. Therefore hermeneutics have levels of emotional influence on the emergence of movements in encountering or backing up so that a misconception interpretation is not a virus that destroys the global Islamic civilization.

The most applicable problem on hermeneutics is the distinction between exegesis (reading the meaning out of the text) and eisegesis (reading our own meaning into the text). There is a presumption that eisegesis is the only valid approach towards the interpretation. The standard of rational exegesis tends to be flexibility. Hermeneutic in Islam is in line with the 'principle hermeneutic' or 'paternalistic (patterned) hermeneutic'. However in philosophy it shows that adorning the meaning of a text in analysis (exegesis) elaborates between the meaning of authentication and asceticism as well as moral/social order towards the possibility of a text meaning (eisegesis) synthetically, all are important aspects of the hermeneutic process.

\section{METHODOLOGY}

\subsection{Understanding the Hermeneutics}

Hermeneutic is derived from the word hermeneuein or hermeneia which has three basic of meanings which are understood in the classical period is "to announce", "to explain" and "to translate". Others interpret hermeneutic with "to express" which is synonymous with "to say" (an opinion). The words above are related to the understanding of a word which is described in the form of a translation of the text language into individualistic spoken language. Hermeneutic is interpreted as "to set forth". The understanding is based on "to explain" is directed to elaborate on the feasibility of the sign/gesture contained in the word. Meanwhile "to interpret" is intended to make clear the unclear text into certain meaningful text that no longer contains vagueness.

The Hermeneutics derivation from Greek is translated "to interpret" is the science which describes the principles or methods of an interpretation of individualistic meaning of the author. In principle, hermeneutic is understood by exegesis and contextual analysis which lead to create the rule of interpretation or an art. ${ }^{3}$ Hermeneutic is identical as an interpretation doctrine that can explain the meaning in deep and shallow, minimum and maximum, transcendent and sophistic, authenticity and engineering. The application of hermeneutic is generally used to denote the art theory or a doctrine theory of what is observed. Hermeneutic is synonymous with exegesis that defined as "to set forth, explain and narrate". Exegesis is also included in the art of expressing word theory. Exegesis is interpreted the same as translation). ${ }^{4}$ In addition, the hermeneutic is interpretations itself that can be understood as revealed by Paul Riecour "interpretation is the work of thought

\footnotetext{
2Ziauddin Sardar, Reading the Qur'an: The Contemporary Relevance of the Sacred Text of Islam, (New York: Oxford University Press, 2011), p. 283

${ }^{3}$ Grant R. Osborne, The Hermentical Spiral: A Comprehensive Introduction to Biblical Interpretation, (USA: Inter Varsity Press, 2006), ed. 2, p. 21

${ }^{4}$ Rita Copeland, Rhetoric, Hermeneutics, and Translation in the Middle Ages: Academic Tradition, (New York: Vambridge University Press, 1995), p. 88 
which consists in deciphering the hidden meaning in the apparent meaning, in unfolding the levels of meaning implied in literal meaning"

Schleirmacher defines hermeneutics as the art in understanding the words that form the truth discourse of various individualistic. Many expressions of hermeneutic application first form discourse before the expression is received as doctrine, dogma and ideology. While Palmer defines hermeneutics as an understanding approach of the man's work tries to describe by transcending the forms of language interpretation.

Language is a tool for human existence. While understanding a state of "loss of self" that an understanding must release itself from the attitude of feeling, emotion and engineering in order to have a level of relevance to the theological hermeneutic. Hermeneutic generally develops in a tradition that has been proven as the building of religion and law, art and philosophy so as to revolute them it is needed tradition awareness through reflection emancipation movement. The interpretation in the hermeneutic application at a minimal level produces only idea but at a maximum level it produces a rule of law, ideology and doctrine that causes an interpretation becomes applied, applicable and even a dogma or a doctrine which must not be violated.

\subsection{Understanding Religion Discourse}

Understanding of religion is always synonymous with a discourse that departs from the texts of Holy Books. Understanding of religion can be done in various ways among them is using the term interpretation, exegesis (opposite of eisegesis), and hermeneutics, in Islam they are known as Tafsir, Ta'wil and fahm of alQur'an. The understanding itself is an offering understanding that can be accepted somewhere and rejected in another place. Understanding is more a reflection and personal experience which interacts with the Holy Books.

Religion is seen as a commitment to all the activities contains the ultimate truth. The behaviors of religious people act on the basis of authentic inner experience against God so that they create the influence of religion in human beings by creating harmony in their life with God. Nevertheless, in religious routines as life obligation it is accepted by any person anywhere. The forms of religion are centered on the community that the essence of religion applies the virtues which seen as the way of realizing themselves in the society. So in this case, it is required an interpretation of the meaning of the deepest religious symbols. Healthy religious people are always inspired in the attitude of optimistic, happy, soul friends (extroverted), the belief in social as the people who have all the views on things and whatever they see always use the power of mind to reveal the good potential. While the religion of sick souls reflects their beliefs in pessimistic, sorrow, suffering and closed personality (introverted).

Understanding of the Holy Books texts aims to obtain a good understanding of the better understanding of oneself (sichversteht) between a person's ability and his culture. Each understanding is sometimes developed through dialogue patterns that must use language media. The interpretation of Holy Books is given an understanding or interpreted to be clear as the centre of peace message. Holy Books substantially belong to interpreters so they interpret them to be light faith. Faith in future life is interpreted by Ludwid Feuerbach with "Life after death", Faith in the future is understood also by applying the truth in life belief. The characteristics of religion understanding cover several types of religion understanding namely, (1) literal sense of scripture, (2) the spiritual sense of scripture, (3) the fuller sense of scripture, and (4) the accommodative sense of scripture. All such sensitivities can be accepted to a certain level in society that sometimes differ in accepting based on the times and places. Each of the times and places there often occur $k u f r$, dhal andkhata' which highly depend on the social dynamics that influenced by social facts or the faith itself. Faith creates the divine truth in order to meet amar makruf nahy munkar. While social faith shapes the religion truth based on the society perception, religion leaders, local and culture leaders.

\section{DISCUSSION}

\section{Hermeneutic of HasanHanafi as a Solution in Understanding Religion at Globalization Era}

Transformation of social and religion is more identical in values movement from the old to the new. The main orientation movement of the contemporary message to the more orientation would require no inheritance of hostility and anger, tahazzub (dogmatic) and ta'asob (fanatical), black and white, and haq and bathi(truth and falsehood). The change of reality is a good step even the change thinking is a virtue in keeping away or leaving the reality. ${ }^{5}$ This puts the understanding of religion as a changeable measure for the better one. The interpretation of Holy Books usually follows the rules of the times and places. New breakthroughs starts from the interpretation to shape the understanding of religion based ongeist (spirit of the age).

${ }^{5}$ Hasan Hanafi, Hiwarar al-'Ajyal, (Kairo: Dar al-Quba, 1998), p. 479

DOI: 10.9790/0837-2203074450 www.iosrjournals.org $\quad$ 46|Page


The transformation will take a form that puts the new order, but many orders sometimes create the issues of need which are not solved in the world, are just drifted. ${ }^{6}$ Through the transformation of thinking in an effort to enlightenment (tanwir) of religion by increasing the religious thought in order to the internalization of values which imperfect the system, can eliminate the efforts in ta'asob (blind fanatic), tasyannhj (discredit), tashallub (violent domination), 'udwanah (hostility) and' uzalah (split) ). ${ }^{7}$

Hermeneutic in Hanafi's perspective embraces the information balance by considering the level of acceptance formulations in the society that ranges among al-maqulat (in line with the sensory knowledge), al'ibarah (matching with the thought that can be correlated), al-qiyas (borrowing logical meaning in related verse). While those belong to the logic of consideration (dhan) are safsatuh (an argument that composed of several premises), al-khitabah (private dialectic), sya'ir (rhetoric) and al-Burhan (demonstrative. ${ }^{8}$ These are concluded from observations of mufassir (commentators) who have various methods of their interpretations so that there has never been found the same interpretation but many gained changes due to various theories of meaning analysis, ${ }^{9}$

Therefore, Hanafi tried to bring conciliation between two antagonistic movements in a Muslim nation that is between the offerings of the secular and the Salafis, although physically the two concepts are contrary, but they still live in a turats (tradition). Hanafi introduced a way of thinking towards religion understanding through a method of left Islamic understanding. The left Islam aims to reconstruct past Islamic heritage with the development pattern of epistemology by considering the traditional aspects rooted from the past, then idealized them into the culture and tradition (turāts). ${ }^{10}$

Hanafi introduced a hermeneutical theory through istimbatistiqra'i approach (deductive exploratory). ${ }^{11}$ Istiqra 'aims to unite the mind and the reality. So the space of istiqra' is obtained through the reality which studied by the method of logical istimbatistiqra'i. Hanafi stressed that both istimbat and istiqra'i reach the truth of yaqin and dhan. Istimbat is interpreted by Tariq Ramadan as 'inference'. Istiqra' is understood as istaqraitu which is interpreted as 'I have tested' by representing a test from special to general through meaning knowledge of each part and its specification. The meaning of istiqra' its implications does not only test a word but know the words which are tested. Istiqra' is an argument formulated based on the particular case represented in the universal. Istiqra 'in Greek is called epagoge. Epagoge is an individual knowledge obtained deductively. Epagoge is meant that the ability to hold the conclusions made from the summit view of the same overall sense in every person or an appreciation of an individual aesthetic which is accepted by people in general.

Hanafi offers a solution by stating that he is interested in nawāżil hermeneutic (big house), not i'tirädiyah hermeneutic (contradictions). In addition to nawāżil hermeneutic, Hanafi still wants hermeneutic within the scope of zawähir, something requires rejection (rafa ') including the acts and actions of hypocrites (zindiq). Hermeneutic by nature is degradation (tasykik) of basic religion. Zawāhir hermeneutic reflects an understanding of religion equation (equality) in order to avoid the perception of conflict in society. Scripture in hermeneutic approach aims to achieve the goal of divine on earth while applications religious understanding adjusted by degradation (tasykīk) the basics of religion. Zawähir includes three characters, they are zahir with grammatical structure, zahir by customs ( 'urf) and zahir with evidence.

The above nuance of mind is as the support of the creation the left Islamic discourse in the development of global civilization. Left Islam is not driven by the ritual and secular power but try to move the future of the conservative as a sense of pleasure to the past by evoking progressive ideas, Islam can move on with its progressivity. The civilization develops from yasāridīn̄ (left religion) towards yamīndīnī (right religion). Yasāridīn̄i is aminimum level of nadar (mind) equality. Al-Yasāris an hard invitation towards the ability to ensure the demand of democracy issues. Al-Yasar in the level of tsaurah (revolution) improves malakuardh (native ruler).

Understanding of left Islam is seen as a conspiracy or rejection attitude towards the irrelevant manifestation. The left Islam prevails progressive ideas, which signals that the teachings of renewable Islam is practical along with the modern conception. The left Islam is the same as the term of new salafiyyin. There is a

\footnotetext{
${ }^{6}$ Reza Aslan, Beyond Fundamentalism: Confronting Religious Extremism in The Age of Globalization, (New York: Random House Publishing, 2009), p. 7 
main contradiction between Muslim communities and the influence of Western imperialism which hastens the improvement of Arab Islamic identity with authenticity values (asala or kekhus rats is the religious past Islamic heritage). Then turāts is growing as a filter in the form of clarification and dissemination.

The essence of hermeneutic existents God on earth as corresponding with the saying in verse ilah alsamāwātiwa al-ardh. Finally Hanafi introduced a kind of hermeneutic like thawali tafsir (cross-border) that is the interpretation which uses surah by surah and verse by verse, and combining between thematic and tikrār repeating the verses). The thematic tafsir collects the whole verses which relate to one theme then all the thematic structures possibly include the whole Islamic knowledge in the scope of human, social pathology and the condition of the country, then it is called revolutionary tafsir it means we find the relationships of Muslims's earth liberation (tahrīruarīdhī) in the name of Allah. The one which ties between Allah and the earth in one arādhu al-mi (the earth fulfills the promise) and lahūtardh (declares God on earth) that is the union between tauhid and wahdatul ummat, between nubuwwah and historical dynamics, the revolution of the earth, the dynamics which eliminate the gap between sukunina (peace) and takhallufina (differences), then these shape the hadhara(civilization) which are mutually inter-connected among man, age, historical and dynamics.

The renewal movement of contemporary Islam requires the removal of ishlahdin (religions reform) to nadhhahsyāmilah' (performance resurrection). Then from nahdhahsyamilah' it will produce mind enlightenment and it will easily create a social and political revolution by itself. Mitsali (ideal) reform leads to social reform, it should be through the mixture of wa'yusiyasi (political discourse) with wa'yutarikhi (historical discourse).

Meanwhile Hanafi required the reform should start from mind and soul first, then followed by hukumah (state) as well as the third to correlate with religion. But he did not concern with aqidah (ideology) reform and uluwwiyahdīnī above politics. The urgency of reform as the trigger of transformation chooses one between the tribe Islah (reform) and the state reform. Then the state reform is more important than the tribe reform. The state reform is the reform of government internalization not externalization. Meanwhile it does not prioritize the external reform by considering that many countries will face with enemies who perform the evils in their homeland.

\section{CONCLUSION}

Hanafi introduced a theory of hermeneutic with istimbātistiqra' $i$ approach (deductive exploration). Istiqra' is understood as istaqraitu which is interpreted as 'I have tested' by representing a test from special to general through meaning knowledge of each part and its specification. Istiqra' is the ability to hold the conclusions made from the summit view of the same overall sense in every person or an appreciation of an individual aesthetic which is accepted by people in general.

Revolutionary hermeneutic aims in relation to Muslims' earth liberation (tahrīruarìdhi $)$ in the name of Allah. arädhu al-mi (the earth fulfills the promise) and lahütardh (declares God on earth) that is the union between tauhid and wahdatulummat, between nubuwwah and historical dynamics, the revolution of the earth, the dynamics which eliminate the gap between sukunina (peace) and takhallufina (differences), then these shape the hadhara(civilization) which are mutually inter-connected among man, age, historical and dynamics. The renewal movement of contemporary Islam requires the removal of ishlahdin (religions reform) to nadhhahsyämilah'(performance resurrection). Then from nahdhahsyamilah' it will produce mind enlightenment and it will easily create a social and political revolution by itself. Mitsali (ideal) reform leads to social reform, it should be through the mixture of wa'yusiyasi (political discourse) with wa'yutarikhi (historical discourse).

Religion becomes a two eyes weapon of Al-Din al-sya'biafyunu (religion protects the people) and AlDin sharkhah al-muththahadin (religion imposes persistence). Al-Din al-sya'biafyunu is more as a transformation movement either minor or major while Al-Din sharkhah al-muththahadin is more synonymous with the revolution of religion movement or revolution of social movement. Thus hermeneutic of Hanafi expects the shape of nawazil hermeneutic and not hermeneutic which attack each other. Besides nawazil hermeneutic, Hanafi still wants the hermeneutic patterned within the scope of zhawahir hermeneutic ie something that requires the rejection of the extremities. Hermeneutic naturally is tasykik (degradation) of its religion fundamentals.

\section{REFERENCES}

[1] Abaza, Mona, Debates on Islam and Knowledge in Malaysia and Egypt: Shifting Worlds, cet. 1, (New York: Routledge, 2002)

[2] Adams, Nicholas, Habermas and Theology, (Cambridge: Cambridge University Press, 2006)

[3] al-'Abdali, IbnuMaqshid, Ashḥabu al-Ta'wīlāt al-Fāsidah: al-Qadīmahwa al-Mu'ashirah, (Lahore: Dār alKitābwa as-Sunnah, 2001), juz. 1.

[4] Al-Buraey, Administrative Development, (New York: Routledge, 1985)

[5] Al-Ghazālī, Al-Mushtashfā min 'Ilmi li ’Ushūl, taḥqīq. Muḥammad Asyqār, (Beirūt: Al-Risālah, juz. 1, cet. 1 . 
[6] Al-Jabiri, Mohammad Abed, Democracy, Human Rights and Law in Islamic Thaought, (London: I. B. Touris, 2009)

[7] Al-Osaimi, Mohammed 'Abd Al-Mohsen, The Persuasion of King Faisal Ibn Abd al-Aziz: A Case In Contemporary Islamic Oratory, (Bloomington: Indiana University, 1990)

[8] Aslan, Reza, Beyond Fundamentalism: Confronting Religious Extremism in The Age of Globalization, (New York: Random House Publishing, 2009)

[9] Ataman, Kemal, Understanding Other Religions: aAl-Biruni's and Gadamer's "Fusion of Horizons," (Washington: The Council Research in Value and Philosophy, 2008)

[10] Barakat, Halim, The Arab World: Society, Culture, and State, (California: University of California Press, 1993).

[11] Black, C. Clifton, Reading Scripture with the Saints, trans. Stephen E. Fowl, (Cambridge: The Lutterworth Press, 2015).

[12] Blass, Rachel B., The Meaning of the Dream in Psychoanalysis: Three Thirteenth-Century Sufi Texts, (New York: State University Of New York Press, 2002)Brogan, Walter A., Heidegger and Aristotle: The Twofoldness of Being, (New York: State University of New York Press, 2005)

[14] Brow, Jeannine K., Scripture as Communication: Introducing Biblical Hermeneutics, (Grand Rapids: Baker Academic, 2007).

[15] Browers, Michaelle L., Democracy and Civil Society in Arab Political Thought: Transcultural Possibilities, (New York: Syracuse University Press, 2006), ed. 1.

[16] Christopher Norris, On Truth and Meaning: Language, Logic and the Grounds of Belief, (London: Continuum International Publishing Group, 2006).

[17] Chung, Paul S., The Hermeneutical Self and an Ethical Difference: Intercivilizational Engagement, (Cambridge: James Clarke, 2012)

[18] Copeland, Rita, Rhetoric, Hermeneutics, and Translation in the Middle Ages: Academic Tradition, (New York: Vambridge University Press, 1995)

[19] Doedes, Jacob Izaak, Manual of Hermeneutics for the writings of the New Testament, tran. G. W. Segman, (Edinburgh: T \&b T Clark, $\mathrm{tt}$ )

[20] Feuerbach, Ludwig, The essence of Christianity, trans. Merian Evans, (London: John Chapman, $t \mathrm{t}$ ).

[21] Fitzmyer, Joseph A., The Interpretation of Scripture: In Defense of the Historical-critical Method, (New Jersey: Paulist Press, 2008).

[22] Gadamer, Hans-Georg, Philosophical Hermeneutics, tran. David E. Linge, (London: University of California Press, 2008).

[23] Gorman, Michael J., Elements of Biblical Exegeisist: A Basic Guide for Students and Ministers, (USA: Baker Publishing Group, 2009)

[24] Hasan Ḥanafī, Al-Dīn Wa al-Śaurah fi Mishr 1952-1981, (Kairo: Madbūlī, 1989), vol. 1.

[25] _ Al-Dīn wa al-Tahaharrur al-Ṡaqafah, (Kairo: Maktabah Madbuli, t.t)

[26] _al-Yamīn wa al-Yasār fi al-Fikri al-Dīn̄̄, (Mesir: Madbuli, 1989)

[27] __ _ _ _ Yl-Yamīn wa al-Yasār fí al-Fikri al-dīni, (Mesir: Madbūlī, 1989).

[28] _ Hiwār al-`Ajyal, (Kairo: Dar al-Quba, 1998)

[29] —— Min al-Naql ilā al-'Ibda', (Kairo: Dār al-‘Aqiba, 2000), Juz. II.

[30] Min al-Nash ilā al-Waqi`: Bunyat al-Nash, Jilid. I dan II, (Kairo: Markaz al-Kutāb li al-Nasyr, 2004)

[31] __ Min al-Nash ilā al-Waqi`: Takwin al-Nash, Jilid. II, (Kairo: Markaz al-Kutāb li al-Nasyr, 2004

[32] _ Ta’wīl al-Zāâhiriyyat, (Kairo: Maktabah al-Nafizah, 2006)

[33] Harrison, Victoria S., Religion and Modern Thought, (London: SCM Press, 2007).

[34] Hill, Kenneth H., Religious Education in Theafrican American Tradition: A Comprehensive Introduction, (Missouri: Chalice Press, 2007)

[35] Hood, Ralph W. et. al, The Psychology of Religion: An Emperical Approach, (New York: The Guilford Press, 1996)

[36] Ibnu Taimiyah, Majmu'ah al-Fatawā Li Syaikh al-Islām, (Riyādh: Matabi` Riyādh, 1963), juz. 17.

[37] Janssens, Jules L., An Annotated Bibliography on Ibn Sina (1970-1989): Including Arabic and Persian Publications and Turkish and Russian References, (Leuven- Belgium: De Wulf Masioncentrum, 1991).

[38] Kassab, Elizabeth Suzanne, Contemporary Arab Thaught: Cultural Critique in Comparative Perspective, ( New York: Columbia University Press, 2010)

[39] Leyh, Gregory (Ed), Legal Hermeneutics: History, Theory, and Practice, (California: California University Press, 1992).

[40] Liere, Frans van dan Franciscus Anastasius Liere, An Introduction to the Medieval Bible, (Cambridge: Cambridge University Press, 2014) 
[41] Macqueen, Benjamin et. al. (ed.), Islam and the Question of Reform: Critical Voices from Muslim Communities, (Australia:Melbourne University Press, 2008).

[42] Metz, Thaddeus, Meaning in Life: An Analiytic Study, (Oxford: Oxford University Press, 2013).

[43] Murphy, Caryle, Passion for Islam: Shaping the Modern Middle East: The Egyptian Experience, (New York: Scribner, 2002).

[44] Osborne, Grant R., TheHermeutical Spiral: A Comprehensive Introduction to Biblical Interpretation, (USA: InterVarsityPrees, 2006), ed. 2.

[45] Palmer, Richard, Hermeneutics, (Evanston: Northwestern University Press, 1969).

[46] Preyer, Gerhard (ed.), Donald Davidson on Truth, Meaning, and the Mental, (Oxford: Oxford University Press, 2012).

[47] Ramadhan, Tariq, Islam and the Arab Awakening, (New York: Oxford University Press, 2012)

[48] Western Muslims and the Future of Islam, (New York: Oxford Universirty Press, 2004)

[49] Ricoeur, Paul, The Conflict of Interpretations, trans. Don Ihde, (Evanton: Northwestern University Press, 1974)

[50] Risser, James, The Life of Understanding: A Contemporary Hermeneutics, (Indiana: Indiana University Press, 2012)

[51] Robinson, James T., Samuel Ibn Tibbon's Commentary on Ecclesiastes: The Book of the Soul of Man, (Tübingen: Mohr Siebeck, 2007)

[52] Rubin, Barry (ed.), Revolutionaries and Reformers: Contemporary Islamist Movements in the Middle East, (New York: State University of New York Press, 2003).

[53] Runciman, W.G. (ed.) Max Weber. Selections in Translation, Cambridge: Cambridge University Press, 1978), h. 171

[54] Sadeghi, Behnam, The Logic of Law Making in Islām: Women and Prayer in the Legal Tradition, (Cambridge: Cambridge University Press, 2013).

[55] Saleh, Fauzan, Modern Trends in Islamic Theological Discourse in 20th Century Indonesia: A Critical Survey, (Leiden: Brill, 2001)

[56] Sardar, Ziauddin, Reading the Qur'ān: The Contemporary Relevance of the Sacred Text of Islām, (New York: Oxford University Press, 2011)

[57] Schleiermacher, Friedrich, Hermeneutics and Criticism: And Other Writings, ed. Andrew Bowie, (Cambridge: Cambridge University Press, 1998), cet. 1.

[58] Seebohm, Thomas M., Hermeneutics. Method And Methology, (Netherland: Kluwer Academic Publisher, 2004)

[59] Sharify-Funk, Meena, Encountering the Transnational: Women, Islām and the Politics of Interpretation, (England: Ashgate Publishing Company, 2008).

[60] Thiselton, Anthony C., Hermeneutics: An Introduction, (Michigan: Wm. B. Eerdman Publishing, 2009).

[61] Tibi, Bassam, Political Islam, World Politics and Europe: Democratic Peace and Euro-Islam Versus Global Jihad, (New York: Routledge, 2008).

[62] Vanhoozer, Kevin J., IsThre a Meaning in This Text?: The Bible, the Reader, and the Morality of LiteralyKowledge, (Michigan: Zondervan, 1998)

[63] Voll, John Obert, Islam: Continuity and Change in the Modern World, (New York: Syracuse University Press, 1994).

[64] Weber, Max, Economy and Society, ed. Guenter Roth and Claus Wittich, (CA: University of California Press., 1978).

[65] Wilber, Ken, Eye to Eye: the Quest for the New Paradigm, (Massachutts: Shabhala Publications, 2001), ed. 4 . 